\title{
Economics of sea buckthorn production and processing in Hungary
}

\author{
Erdős, A. D. \& Szőllősi, L. \\ University of Debrecen, Faculty of Economics and Business, Institute of Applied Economics Sciences; \\ H-4032 Debrecen, Böszörményi Street 138. \\ Author for correspondence: Erdös, A. D. (erdos.adel@gmail.com)
}

\begin{abstract}
Summary: This study focuses on the business management-related advantages and disadvantages of sea buckthorn production and processing based on economic analyses. It is the main objective of the authors to identify the expected economic findings in a high standard plantation with different average yields. A deterministic model calculation was performed on the basis of technological processes, using the primary data collected from enterprises dealing with sea buckthorn production. The calculation is based on the assumption of a 10 hectare plantation with intensive production technology (high soil quality (golden crown value: $32 \mathrm{GC}$ per ha), irrigation, high plant density per hectare). The cost and income relations and the long-term return of the plantation were examined in the case of different average yields $\left(12 \mathrm{t} \mathrm{ha}^{-1}, 18 \mathrm{tha}^{-1}\right.$ and $\left._{24} \mathrm{t} \mathrm{ha}^{-1}\right)$. Under the economic circumstances of 2016, the planting cost of an intensive plantation is around 4-4.1 million HUF ha ${ }^{-1}$. In the years following the fruit-bearing stage, direct production costs are between 2.5-3.9 million HUF ha ${ }^{-1}$, depending on the given average yield. On the contrary, 5.6-11.1 million HUF ha ${ }^{-1}$ revenue can be reached based on the current market prices, resulting in a gross margin of 3.1-7.1 million HUF ha ${ }^{-1}$. Under the modelled circumstances, return is realised on the plantation's costs in 6-8 years. The net present value $\left(\mathrm{NPV}_{\mathrm{r}=3.24 \%)}\right.$ calculated for the 15-year-long life cycle of the 10-hectare plantation is between 151-466 million HUF, while the internal rate of return (IRR) is between 23-45\%. From the business management aspect, the advantage of sea buckthorn production is that it provides better income and return at a planting cost which is similar to that of other small fruits and berries. At the same time, the disadvantage of sea buckthorn production is the fact that yields are harvested every two years due to the technological characteristics of harvesting. The negative impact of this bi-yearly yield on liquidity can be eliminated with the so-called delayed planting.
\end{abstract}

Erdős, A. D., Szőllősi, L. (2018): Economics of sea buckthorn production and processing in Hungary. International Journal of Horticultural Science 24(3-4): 21-25. https://doi.org/10.31421/IJHS/24/3-4./2049

Key words: sea buckthorn plantation, average yield, economic analysis, return, simulation model

\section{Introduction}

Sea buckthorn (Hippophae rhamnoides) is not a well-known plant in Hungary, but an increasing number of farmers establish plantations by means of organic farming due to its beneficial effect on the human body. Sea buckthorn is called "the queen of healing fruits" due to its 250 different ingredients, such as omega-3 and omega-6 fatty acids, various vitamins, as well as calcium and magnesium (Seléndy, 2013). According to the data of the Hungarian Central Statistical Office (HCSO), sea buckthorn was produced on around 100 hectares in Hungary in 2015. For today, this area is close to 300 hectares. Between 2006 and 2015, the average yield of sea buckthorn in Hungary ranged between 0.8-4.9 $\mathrm{t} \mathrm{ha}^{-1}$ (HCSO, 2016). Currently, the market is still not saturated, while demand is constantly increasing. Sea buckthorn is usually sold either as berries or pulp. In practice, more sea buckthorn is sold as berries. The most widespread Altai varieties in Hungary include "Yantarnaya", "Orangevaya", "Chuiskaya" and "Obilnaya", while the most popular German varieties in Europe are "Hergo", "Leikora", "Oskola" and "Habego" (Seléndy, 2013; Höhne, 2015).

As regards scale, sea buckthorn plantation sizes range from 1-2-hectare farms to enterprises with 10-20-hectare plantations which include both extensive and intensive production technology. The reason for using extensive technology is usually lower quality soil (below 20 golden crown per ha), lack of irrigation and sparse spacing $(4 \times 2 \mathrm{~m}$ row and stem spacing) which is able to produce $2-8 \mathrm{tha}^{-1}$ on average. On the contrary, in the case of intensive technology, soil quality is good (above 20 golden crown per ha), the land is irrigated and spacing is dense $(4 \times 1.67 \mathrm{~m}$ row and stem spacing), resulting in average yields between $12-25 \mathrm{t} \mathrm{ha}^{-1}$.

According to the observations of Papp \& Porpáczy (1999), irrigation may even double specific yield. In addition, based on the viewpoint of Li (1997), sea buckthorn demands irrigation especially in the spring, when fruits start to develop. Höhne (2015) concluded that the availability of water is especially important when choosing the proper soil for a plantation and the results of the performed examinations also show that plants developed twice as big berries on irrigated lands than on nonirrigated sites.

According to Voigt et al. (2016), the appearance and damage done by the sea buckthorn fly have been reported in certain countries of Northern Europe. The sea buckthorn fly is able to totally damage the fruit, resulting in shrivelled and dry berries. At the same time, the sea buckthorn fly is not expected to appear in Hungary in the medium term.

Consequently, the authors of this paper think that the economic relations of sea buckthorn production and processing 
need to be examined under Hungarian circumstances. It is the main objective of this study to determine the cost and income relations, as well as the return of high standard intensive plantations in the case of various average yields. Consequently, this paper looks for the answer to the following questions: 1) How can the technological and economic characteristics of an intensive sea buckthorn plantation be described? 2) What are the cost and income relations of the various examined average yields? 3) What is the long-term return of the plantation depending on specific yields? The proper answers to these questions help identify the advantages and disadvantages of sea buckthorn production and processing which greatly influence farmers' potential intention to establish and invest into a plantation.

\section{Materials and methods}

The necessary primary data were collected from several sea buckthorn producers during the research work. Data collection involved the technological, natural and specific economic data concerning planting, nursing until the fruit-bearing stage, as well as production and processing after the fruit-bearing stage. Considering the 2016 prices of the inputs used during the activity, operational data were also supplemented with data originating from other sources. We used the data of Gockler (2016) when determining the machinery costs of operations related to planting and nursing, such as soil analysis, soil preparation, hole drilling needed for planting, applying organic manure in the holes, grassing between rows and mowing. The specific costs of establishing the irrigation system were calculated in accordance with the conditions set out in the call for tenders titled "Modernisation of horticulture - supporting the establishment of plantations with irrigation systems" (Reszkető, 2015). Personnel costs were set to 1000 HUF per hour gross. The material costs of certain items (grass-seed, shrink foil, work gloves, pruning shears and loppers) were determined on the basis of agricultural retail prices, while we used the operational data of sea buckthorn producers for others (cuttings, big bags, bag in box). The costs of postharvest operations (transport, blast chilling, destemming, cleaning, cold storage, pulp extraction) were also based on producers' data. The output prices are in accordance with the 2016 price level and were determined using a priori estimation based on interviews conducted with producers.

Based on the collected and processed data (Table 1), a model calculation was performed for a sea buckthorn plantation which is suitable for the conditions of intensive production technology - dense spacing, irrigated and high soil quality. The scale of calculation was set to 10 hectares. The models are built on technological processes and involve all operations related to planting, nursing until the fruit-bearing stage, as well as nursing, production and processing after the fruit-bearing stage in detail. Due to the technological peculiarities of harvesting sea buckthorn, the plantation produces yield every two years. For this reason, a so-called delayed planting was taken as a basis (planting 5 hectares in the first year and 5 hectares in the second year), which eliminates the resulting liquidity problems.

Postharvest activities involve several operations. As a first step, chopped twigs are placed into a bin of $300 \mathrm{~kg}$ capacity, which is then wrapped into $40 \mathrm{~m}$ long shrink foil in order to facilitate more stable transport. 24 bins, i.e., $7200 \mathrm{~kg}$ chopped twigs can be transported in a truck. As a next step, blast chilling is performed in order to shake off the berries the safest way possible without causing them any damage. Berries are stored in cold storage on pallets in big bags of $900 \mathrm{~kg}$ capacity for approximately 90 days.

Table 1. Boundary conditions of the model calculation

\begin{tabular}{|l|c|}
\hline \multicolumn{1}{|c|}{ Description } & Data \\
\hline Scale (ha) & 10 \\
\hline Stock name & Hergo \\
\hline Row spacing (m) & 4 \\
\hline Stem spacing (m) & 1.67 \\
\hline Plant density per hectare (number of plants per ha) & 1500 \\
\hline Golden crown value of the land $\left(\mathrm{GC} \mathrm{ha}^{-1}\right)$ & 32 \\
\hline Irrigation system & yes \\
\hline Fence & yes \\
\hline Drained net weight of bin (kg per bin) & 300 \\
\hline Shrink foil use (m per bin) & 40 \\
\hline Capacity of transport vehicle $\left(\mathrm{kg} \mathrm{per} \mathrm{truck)}^{-1}\right)$ & 7200 \\
\hline Pallet capacity (kg per pallet) & 900 \\
\hline Cold storage (number of days) & 90 \\
\hline Volume of bag in box (litre per bag in box) & 3 \\
\hline Proportion of berries to be sold (\%) & 65 \\
\hline Proportion of pulp to be processed $(\%)$ & 35 \\
\hline Pulp recovery rate (l kg $\left.{ }^{-1}\right)$ & 0.75 \\
\hline Selling price of berries (HUF kg $\left.{ }^{-1}\right)$ & 600 \\
\hline Selling price of pulp (HUF $\left.{ }^{-1}\right)$ & 2000 \\
\hline Subsidies (SAPS + greening) $\left(\mathrm{HUF} \mathrm{ha}^{-1}\right)$ & 6980 \\
\hline
\end{tabular}

Source: Own data collection

The proportion of berries and pulp intended for sales purposes is different, as the share of berries is $65 \%$ and that of pulp is $35 \%$. 0.751 pulp can be extracted from $1 \mathrm{~kg}$ berries. The produced $100 \%$ pulp is sold in 31 bag in boxes for 2000 HUF per litre. On the contrary, the selling price of berries is $600 \mathrm{HUF} \mathrm{kg}^{-1}$.

The simulation model is operated in a deterministic way and the results interpreted in terms of the boundary conditions can be derived from the input data. In the case of the expenses and revenue assigned to each operation, as well as the inputoutput prices, the costs and revenue of the activity can be determined. A cost benefit analysis (CBA) was performed based on these model output data. Production costs were derived for each operation and both direct and indirect costs were involved in the calculation. In the case of efficiency indexes, profitability, labour intensity and productivity indexes were also involved.

The long-term return of the plantation was analysed with dynamic investment economy indicators (NPV, DPP, IRR) in accordance with Szőllösi \& Szücs (2013). The benchmark of treasury bills and government bonds were taken as a basis when determining the discount rate. The discount rate was set based on the benchmark of 15-year government bonds (3.24\%) in accordance with the Government Debt Management Agency Ltd. (GDMA, 2016). Both cash flows and the calculative interest rate were calculated at nominal value. Therefore, price level change was taken into consideration both on the input and the output side due to the several year-long life cycle of the plantation. Based on the interviews conducted with producers, 
$2 \%$ price level change is expected in terms of costs (except for depreciation) and $1 \%$ price level change is expected with regard to selling prices.

\section{Results and discussion}

The investment period of the sea buckthorn plantation covers 3 years, which involves planting and the subsequent 2 years of nursing. The costs of planting are shown by Table 2 , broken down to operation. It can be clearly concluded that the main cost factor is represented by planting cuttings ( 1500 cuttings per hectare) which costs more than 2 million HUF per hectare and accounts for around 54\% of all planting costs. In addition, the establishment of a micro-sprinkler irrigation system also has a high cost $(750$ thousand HUF ha-1). As regards other direct costs in addition to the registry and supervision fees of Biokontroll Hungária Nonprofit Ltd. and the contribution to mitigate damages, one also has to consider the fee of water extraction permit. The share of costs incurred as further items is relatively low. Altogether, the planting cost of an intensive sea buckthorn plantation is 4-4.1 million HUF ha ${ }^{-1}$.

Table 2. Planting costs

\begin{tabular}{|l|c|c|}
\hline \multicolumn{1}{|c|}{ Operations } & $\begin{array}{c}\text { Costs } \\
\text { (thousand } \\
\text { HUF } \text { ha }^{-1}\end{array}$ & $\begin{array}{c}\text { Distribution } \\
(\%)\end{array}$ \\
\hline Soil preparation & 253 & 6.2 \\
\hline Grassing & 25 & 0.6 \\
\hline Preparation of planting & 137 & 3.4 \\
\hline Planting & 2180 & 53.7 \\
\hline Establishment of irrigation system & 750 & 18.5 \\
\hline Permits, technical supervision & 210 & 5.2 \\
\hline Irrigation & 15 & 0.4 \\
\hline Building a fence & 290 & 7.1 \\
\hline Other costs & 198 & 4.9 \\
\hline Total & $\mathbf{4 ~ 0 5 8}$ & $\mathbf{1 0 0 . 0}$ \\
\hline
\end{tabular}

Source: Own calculation

Following establishment, the sea buckthorn plantation needs two years of nursing before the fruit-bearing stage. During the nursing stage, one has to calculate with mowing between rows and plants, irrigation and other direct costs which equal to around 270 thousand HUF ha $^{-1}$ in each year. As a result, the investment cost of the plantation for three years reaches 4.6 million HUF $\mathrm{ha}^{-1}$. Due to the 15-year-long life cycle of the plantation, the yearly depreciation exceeds 300 thousand HUF per hectare.

The first harvesting of the plantation is performed in the $4^{\text {th }}$ year after planting, but only $50-60 \%$ of the whole yield can be expected. $100 \%$ yield can be harvested during the first subsequent harvesting ( $6^{\text {th }}$ year). As a result of delayed planting, only half of the plantation produces yield in a year following the fruit-bearing stage. Therefore, in this model, harvesting is performed only on 5 hectares each year. The incurred production costs were analysed in relation to this part of the plantation in the case of different average yields $(12 \mathrm{t}$ $\left.\mathrm{ha}^{1}, 18 \mathrm{t} \mathrm{ha}^{1}, 24 \mathrm{t} \mathrm{ha}^{1}\right)$. Production costs were 4.4 million HUF $\mathrm{ha}^{-1}$ in the case of the lowest specific yield, while they amounted to 7.3 million HUF per hectare in the case of the highest specific yield. The highest cost items included harvesting, destemming, cleaning and pulp extraction, which represent a cost of more than 1 million HUF ha- ${ }^{-1}$.

The direct production cost of $1 \mathrm{~kg}$ berry is between 304-364 HUF $\mathrm{kg}^{-1}$, depending on average yield. The higher the amount of yield harvested from one unit of land is, the lower the direct production cost of $1 \mathrm{~kg}$ berry is. Of this cost, destemming and cleaning accounts to $80 \mathrm{HUF} \mathrm{kg}^{-1}$, while pulp extraction accounts for $60 \mathrm{HUF} \mathrm{kg}^{-1}$. Harvesting cost has a broader spectrum, as it ranges around 60-80 $\mathrm{HUF} \mathrm{kg}^{-1}$.

While one half of the whole plantation (10 ha) produces yield, the other half needs nursing. During the nursing period, the incurred costs are in relation to mowing between rows and plants, irrigation, other direct costs and depreciation. It has to be noted that no nutrient replenishment and plant protection activities are performed, because the authorised chemicals within ecologic farming have rather limited access. In addition, the producers contacted during data collection did not use these chemicals either, which partly shows the "endurance" of the plant. The total direct production cost of the part of the plantation which only needs nursing is around 580 thousand HUF per hectare.

Table 3 shows production costs for one hectare regarding the whole plantation (10 ha). This amount includes the costs of the 5 ha part of the plantation which produces yield and the other 5 hectares which need nursing activities.

Table 3. Yearly production costs per operation at farm level in the case of various average yields (thousand HUF ha-1)

\begin{tabular}{|c|c|c|c|}
\hline \multirow{2}{*}{ Operations } & \multicolumn{3}{|c|}{ Average yield } \\
\hline & $12 \mathrm{t} \mathrm{ha}^{-1}$ & $18 \mathrm{tha}^{-1}$ & $24 \mathrm{t} \mathrm{ha}^{-1}$ \\
\hline Mowing & 46 & 46 & 46 \\
\hline Irrigation & 30 & 30 & 30 \\
\hline Harvesting & 472 & 591 & 710 \\
\hline Logistics & 211 & 275 & 339 \\
\hline Freezing & 255 & 345 & 435 \\
\hline Destemming, cleaning & 492 & 719 & 946 \\
\hline Cold storage & 99 & 141 & 190 \\
\hline Pulp extraction & 367 & 551 & 735 \\
\hline Depreciation & 307 & 307 & 307 \\
\hline Other direct costs & 198 & 198 & 198 \\
\hline $\begin{array}{l}\text { Total direct } \\
\text { production costs }\end{array}$ & 2477 & 3203 & 3936 \\
\hline
\end{tabular}

Source: Own calculation

Based on the amount of costs calculated for the whole plantation ( 5 ha harvested, 5 ha nursed), it can be concluded that the most expensive operations are destemming and cleaning, the proportion of which is $20-24 \%$, depending on average yield. The second highest cost item is harvesting (18$19 \%)$, while the third is pulp extraction (15-19\%). The depreciation of the plantation, as a fixed cost, decreases from $12 \%$ to $8 \%$, depending on the examined specific yields. Further variable costs include logistics, freezing and cold storage. Altogether, the direct production costs at farm level range between 2.5-3.9 million HUF $\mathrm{ha}^{-1}$, depending on the given

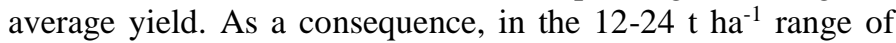
specific yield, each ton surplus yield increases the direct cost per hectare by 120-125 thousand HUF on average.

The direct production costs for $1 \mathrm{~kg}$ berry at farm level were also determined, as shown in Table 4, broken down to 
operation. It can be observed that the direct production cost for one unit of product gradually decreases with the increase of specific yield. If yield is $12 \mathrm{t} \mathrm{ha}^{-1}$, the direct production cost is 413 HUF $\mathrm{kg}^{-1}$, while twice as high specific yield results in significantly lower total direct costs $\left(328 \mathrm{HUF} \mathrm{kg}^{-1}\right)$. In the $12-$ $24 \mathrm{t} \mathrm{ha}^{-1}$ range of average yield, one ton yield surplus reduces the cost for one unit of product by 7-7.5 HUF on average.

Table 4. Direct production costs for $1 \mathrm{~kg}$ berry at farm level in the case of different average yields ( $\mathrm{HUF} \mathrm{kg}^{-1}$ )

\begin{tabular}{|c|c|c|c|}
\hline \multirow{2}{*}{ Operations } & \multicolumn{3}{|c|}{ Average yield } \\
\hline & $12 \mathrm{tha}^{-1}$ & $18 \mathrm{tha}^{-1}$ & $24 \mathrm{tha}^{-1}$ \\
\hline Mowing & 7.6 & 5.1 & 3.8 \\
\hline Irrigation & 5.0 & 3.3 & 2.5 \\
\hline Harvesting & 78.6 & 65.7 & 59.2 \\
\hline Logistics & 35.2 & 30.6 & 28.3 \\
\hline Freezing & 42.5 & 38.3 & 36.3 \\
\hline Destemming, cleaning & 82.0 & 79.8 & 78.8 \\
\hline Cold storage & 16.5 & 15.7 & 15.9 \\
\hline Pulp extraction & 61.3 & 61.3 & 61.3 \\
\hline Depreciation & 51.2 & 34.1 & 25.6 \\
\hline Other direct costs & 33.0 & 22.0 & 16.5 \\
\hline $\begin{array}{l}\text { Total direct } \\
\text { production costs }\end{array}$ & 412.8 & 355.9 & 328.0 \\
\hline
\end{tabular}

Source: Own calculation

In the model calculation, both the production value and income related to the 10 ha fruit-bearing plantation were determined at the 2016 price level (Table 5). Nearly 5.6 million HUF production value can be reached in the case of $12 \mathrm{t} \mathrm{ha}^{-1}$ average yield, while twice as high yield results in 11 million HUF production value. On the contrary, the direct production cost increases only by $59 \%$ as a result of the change of the examined yields; therefore, the amount of gross margin increases from 3.1 million HUF to 7.1 million HUF. When considering the calculable indirect costs, the plantation is able to produce a yearly net income of 2.6-6.6 million HUF at farm level.

Table 5. Yearly production value and income at farm level in the case of different average yields

\begin{tabular}{|c|c|c|c|c|}
\hline \multirow{2}{*}{ Description } & \multirow{2}{*}{ Unit } & \multicolumn{3}{|c|}{ Average yield } \\
\hline & & 12 t ha $^{-1}$ & $18 \mathrm{t} \mathrm{ha}^{-1}$ & 24 t ha $^{-1}$ \\
\hline Sold berries $(65 \%)$ & $k g h a^{-1}$ & 7800 & 11700 & 15600 \\
\hline Selling price (berries) & $H U F k^{-1}$ & 600 & 600 & 600 \\
\hline Sold pulp (35\%) & $l h a^{-1}$ & 3150 & 4725 & 6300 \\
\hline Selling price (pulp) & $H U F l^{-1}$ & 2000 & 2000 & 2000 \\
\hline Revenue & \multirow{8}{*}{$\begin{array}{l}\text { thousand } \\
\text { HUF ha-1 }\end{array}$} & 5490 & 8235 & 10980 \\
\hline Subsidies & & 70 & 70 & 70 \\
\hline Production value & & 5560 & 8305 & 11050 \\
\hline Direct production cost & & 2477 & 3203 & 3936 \\
\hline Indirect cost & & 493 & 493 & 493 \\
\hline $\begin{array}{l}\text { Total production } \\
\text { cost }\end{array}$ & & 2970 & 3696 & 4430 \\
\hline Gross margin & & 3083 & 5102 & 7113 \\
\hline Net income & & 2590 & 4609 & 6620 \\
\hline
\end{tabular}

Source: Own calculation
Table 6 summarises the main efficiency indicators of the plantation. Based on the direct prime costs, it can be concluded that both berries and pulp can be produced at a very favourable prime cost level in comparison with the selling price. In the case of a less favourable average yield, berries provide a gross

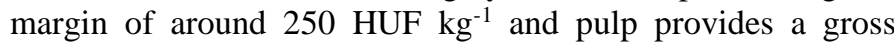
margin of around $1300 \mathrm{HUF}^{-1}$, while the same values are 335 HUF $\mathrm{kg}^{-1}$ and $1400 \mathrm{HUF}^{\mathrm{l}-1}$, respectively, in the case of a more favourable specific yield. Consequently, the cost-related profitability of this activity can be regarded favourable from all aspects.

When analysing labour needs, it can be concluded that increasing specific yields result in increasing labour use per hectare and the labour demand of producing one unit of product is increasingly favourable. As regards labour productivity, the amount of gross margin to be reached per hour is between 7.3-11.4 thousand HUF.

Table 6. Efficiency indicators

\begin{tabular}{|c|c|c|c|c|}
\hline \multirow{2}{*}{ Description } & \multirow{2}{*}{ Unit } & \multicolumn{3}{|c|}{ Average yield } \\
\hline & & $12 \mathrm{t} \mathrm{ha}^{-1}$ & $18 \mathrm{t} \mathrm{ha}^{-1}$ & $24 \mathrm{tha}^{-1}$ \\
\hline $\begin{array}{l}\text { Direct prime cost } \\
\text { (berries) }\end{array}$ & $H U F k^{-1}$ & 348 & 292 & 265 \\
\hline $\begin{array}{l}\begin{array}{l}\text { Direct prime cost } \\
\text { (pulp) }\end{array} \\
\end{array}$ & $H U F l^{-1}$ & 710 & 632 & 593 \\
\hline $\begin{array}{l}\text { Cost-related } \\
\text { profitability }\end{array}$ & $\%$ & 87 & 125 & 149 \\
\hline $\begin{array}{l}\text { Labour needs per } \\
\text { one hectare }\end{array}$ & hour ha-1 & 419 & 522 & 624 \\
\hline $\begin{array}{l}\text { Labour needs per } \\
\text { one unit of product }\end{array}$ & hour $t^{-1}$ & 70 & 58 & 52 \\
\hline $\begin{array}{l}\text { Labour } \\
\text { productivity* }\end{array}$ & HUF hour ${ }^{-1}$ & 7351 & 9778 & 11398 \\
\hline
\end{tabular}

*Gross margin / manual working hours

Source: Own calculation

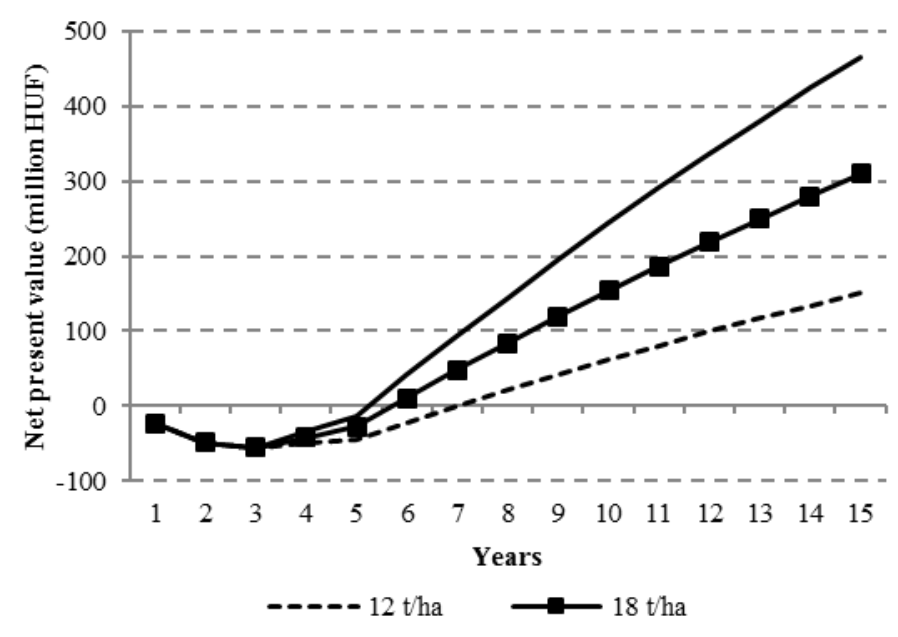

Figure 1. Net present value of the plantation in the case of different Source: Own calculation average yields

Following the profitability evaluation of the sea buckthorn plantation, the long-term return analysis is performed. The net present value $\left(\mathrm{NPV}_{\mathrm{r}=3.24 \%)}\right.$ of each average yield of the investment is shown in Figure 1. A return is realised in all three cases. However, there are rather significant differences between net present values: 151 million HUF $\left(12 \mathrm{t} \mathrm{ha}^{-1}\right.$ average yield), 310 million HUF (18 t ha-1 average yield), or even 467 million HUF (24 $\mathrm{t} \mathrm{ha}^{-1}$ average yield). The internal rate of return (IRR) is $23 \%$ in the most unfavourable case, $36 \%$ in an 
average case and $45 \%$ in a favourable case. A 2-year difference can be observed in the discounted payback period ( $\left.\mathrm{DPP}_{\mathrm{r}=3.24 \%}\right)$. The payback period of a plantation producing $18 \mathrm{t} \mathrm{ha}^{-1}$ and $24 \mathrm{t}$ $\mathrm{ha}^{-1}$ is 6 years, while it is 8 years in the case of $12 \mathrm{tha}^{-1}$ specific yield.

\section{Discussion}

Based on the obtained findings, the business managementrelated advantages and disadvantages of sea buckthorn production can be summarised as follows.

The planting cost of an intensive sea buckthorn plantation is between 4-4.1 million HUF ha-1 ${ }^{-1}$ In terms of scale, this value equals the data published by Apáti $(2014 b ; 2014 c)$ in terms of blackberry and raspberry. For this reason, the planting of sea buckthorn does not represent any extra cost in comparison with other small fruits and berries. As regards production technology, it has to be emphasised that this plant does not call for any special nursing activities and the Hungarian climatic endowments are favourable for its production.

At high cost level, the sea buckthorn plantation is capable of providing high yields and it is "grateful" for irrigation and high soil quality. In the case of the examined average yields, the production value is significantly higher than the production cost; therefore, the $87 \%$ cost-related productivity to be achieved in the case of $12 \mathrm{t} \mathrm{ha}^{-1}$ specific yield can be considered rather favourable in comparison with other small fruits and berries (Apáti, 2014a; 2014b; 2014c; 2014d). According to Apáti (2014c), raspberry production is unprofitable in the case of similarly proper production standards, $10 \mathrm{t} \mathrm{ha}^{-1}$ specific yield and average selling price in an average year. In addition, elderberry is not able to provide such income if similar production standards are provided (Apáti, 2014d). In the case of average (18 tha $\left.\mathrm{ha}^{-1}\right)$ specific yield, sea buckthorn is capable of providing a yearly net income of 4.6 million HUF at farm level, which represents a $125 \%$ costrelated profitability.

Based on the performed calculations, it can also be concluded that it is worth establishing an intensive sea buckthorn plantation, since return is realised on the investment in 6-8 years, depending on the average yield and the internal rate of return is rather favourable (23-45\%).

In comparison with the calculations performed by Apáti (2014c) for raspberry, the labour needs of sea buckthorn are significantly more favourable, even if harvesting is done manually.

As a consequence, it can be concluded that the results of the calculations presented in this study confirm the statement of Apáti (2014a), i.e., sea buckthorn has proper business management characteristics and outstanding profitability.

As a matter of course, there are also disadvantages of sea buckthorn production, including the bi-yearly yield and revenue of the plantation due to the technological characteristics of sea buckthorn harvesting. At the same time, if delayed planting is performed during the establishment of the plantation, the resulting problems can be eliminated. The establishment of a 10 ha plantation costs even up to 50-60 million HUF until it reaches the fruit-bearing stage; therefore, it calls for a significant capital investment in absolute terms. In addition, sea buckthorn fly appeared in Northern Europe and there is still no proper protection against this pest. From this aspect, this factor can be regarded as a potential risk in the future. It is also a disadvantage that there is still no uniform and high volume commodity fund for the processing industry in Hungary, which limits the selling proportion of processed (pulp) products at the enterprise level.

\section{Acknowledgements}

争

Supported through the New National Excellence Program of the Ministry of Human Capacities

\section{References}

Apáti, F. (2014a): A bogyós gyümölcsök helyzetértékelése. Kertészet és Szőlészet. 63(42): 16-17.

Apáti F. (2014b): A málna- és a szedertermesztés gazdaságossága. Kertészet és Szőlészet. 63(44): 18-19.

Apáti, F. (2014c): Farm economic evaluation of raspberry production. International Journal of Horticultural Science. 20 (3-4): 53-56. https://doi.org/10.31421/IJHS/20/3-4/1135

Apáti, F. (2014d): Farm economic evaluation of elderberry production. International Journal of Horticultural Science. 20(3-4): 57-60. https://doi.org/10.31421/IJHS/20/3-4/1136

GDMA (2016): Referenciahozamok. Government Debt Management Agency Ltd.: http://www.akk.hu/hu/oldal /statisztika\#historikus-adatok, Accessed: 21/10/2016.

Gockler, L. (2016): A mezőgazdasági gépi munkák várható költsége 2016-ban. Agrárágazat. 17 (1): 158-170.

HCSO (2016): Hungarian Central Statistical Office: http://www.ksh.hu, Accessed: 07/08/2016.

Höhne, F. (2015): Overview of cultivation technologies and their challenges. In: Sanna, K., Ekaterina, P., eds. Producing Sea Buckthorn of High Quality. Natural Resources and bioeconomy studies 31/2015. Proceedings of the third European Workshop on Sea Buckthorn EuroWorks 2014. 1416 October 2014, Naantali, Finland, 31-35.

Li, T.S.C. (1997): Sea Bucthorn Production Guide. http://www.seabuckthorn.com/prodgdpdf.pdf, Accessed: 07/08/2016.

Papp, J., Porpáczy, A. (1999): Szeder, ribiszke, köszméte, különleges gyümölcsök: Bogyósgyümölcsüek II. Mezőgazda Kiadó. Budapest, 246.

Reszkető T., eds. (2015): Vidékfejlesztési Program Kézikönyv. NAK, Budapest, 92.

Seléndy, J. (2013): Gyakorlati biogazdálkodás I. Mezőgazda Kiadó, Budapest, 151.

Szőllősi, L., Szűcs, I. (2013): Beruházási döntéseket támogató módszerek. In: Felföldi J., eds. Döntéstámogató módszerek és rendszerek. Debreceni Egyetem, Debrecen, 168.

Voigt, E., Samanszkaja, L.D., Lerche, S., Holz, U., Kerber, A., Henning, R., Tóth, M. (2016): A homoktövislégy fokozódó kártétele Észak-Európában és rajzásmegfigyelésére alkalmas csapdatípus kidolgozása. Agrofórum extra. 27(63): 81-83. 